\title{
Who Gets What: The Economy, Relative Gains and Brexit
}

\author{
Jane Green ${ }^{1 \star}$ (D), Timothy Hellwig ${ }^{2}$ (D) and Edward Fieldhouse ${ }^{3}$ (D) \\ ${ }^{1}$ Nuffield College, University of Oxford, Oxford, UK, ${ }^{2}$ Department of Political Science, Indiana University, Bloomington, IN, \\ USA and ${ }^{3}$ School of Social Sciences, University of Manchester, Manchester, UK \\ ${ }^{\star}$ Corresponding author. E-mail: jane.green@nuffield.ox.ac.uk
}

(Received 24 July 2019; revised 3 March 2020; accepted 26 August 2020; first published online 16 February 2021)

\begin{abstract}
There has been a lively debate about the economic and cultural-based drivers of support for populism. This article argues that economic concerns matter, but that they are realized through the relative gains and losses of social groups. Using new survey items in a large representative survey administered in Britain, it shows that citizens' economic assessments of the ethnic minority out-group - in relation to the group's situation 12 months ago and to assessments of the economic conditions of the white British in-group - are a predictor of support for Brexit. The results, which are robust to prior referendum vote, immigration attitudes and cultural sentiment, extend across income groups and national identity strength. Extending the analysis to a comparison of geographic in- and out-groups between local communities and London lends additional support to the argument. The implications of relative group-based economics are important for understanding Brexit and the economic sources of support for populism more broadly.
\end{abstract}

Keywords: status threat; relative gains; group economic voting; populism; Brexit

Is support for Donald Trump, Brexit, and other populist parties and movements driven by economic grievances, or are these votes the result of concerns about the nature and pace of cultural change? How can we bridge the gap between research that finds a strong association between local economic performance and aggregated support for populism, but stronger individual-level evidence of the effects of concerns related to immigration? These questions are central to understanding recent political developments in Britain and the United States, and the rise of populist movements and parties in Western Europe and further afield. They raise conceptual questions about measurement and causal inference, as well as substantive questions about the historic political consequences of major economic and policy shifts.

This article puts forward a conceptualization of the economic vote for populism, Group-Based Economics, which we test in the context of Britain's support for leaving the European Union (Brexit). Our theory draws on evidence about the potential for people to care about the economic gains and losses of groups (Mutz and Mondak 1997). However, rather than focusing on economic inequalities between the rich and poor, we build on connections between sources of economic resentment and populism (Cramer 2016; Gest, Reny and Mayer 2018; Gidron and Hall 2017; Gest 2016), often through forces of globalization, immigration and economic grievance (Becker, Fetzer and Novy 2017; Carreras, Carreras and Bowler 2019; Colantone and Stanig 2018; Jennings and Stoker 2017; Margalit 2012; Pardos-Prado and Xena 2019). Using a novel conceptualization, we theorize about the importance of economic group-based comparisons constructed by ethnicity - the economic evaluations of ethnic minorities, and comparisons of ethnic minorities with the white population. We also extend this reasoning to group-based comparisons based on geography - contrasting the economic standing of one's local community with that of

(c) The Author(s) 2021. Published by Cambridge University Press. This is an Open Access article, distributed under the terms of the Creative Commons Attribution licence (http://creativecommons.org/licenses/by/4.0/), which permits unrestricted re-use, distribution, and reproduction in any medium, provided the original work is properly cited. 
metropolitan cities. We argue that perceptions of economic gains for 'out-groups' (Kinder and Kam 2009) - particularly relative to one's 'in-group' - are key to understanding the basis of economic grievances. Such relative gains motivate people to vote against the status quo, in favour of causes and campaigns that advocate improving the conditions of in-groups.

Insofar as their messages appeal to group-based winners relative to losers, economic groupbased assessments are especially important for levels of support for populist causes and candidates. Our argument about relative economic experiences leads to a new individual-level measure of economic perceptions. This approach is consistent with claims about both the geographic bases of populism and about race and cultural resentment. It allows direct comparison with existing measures of economic voting, attitudes towards immigration and other factors driving political behaviour.

We find support for our group-based economic voting argument, which focuses primarily on distinctions based on immigration (comparing the perceived economic gains of minorities and white Britons) and geography (contrasting the perceived economic gains of Londoners and the respondent's local community). Our analyses draw on new survey questions fielded in a large nationally representative survey, the British Election Study (BES) Internet Panel, and are supported by a research design that takes advantage of the BES panel design. The results hold when we control for prior Brexit vote choice in a previous survey wave, are not fully accounted for by attitudes about immigration, authoritarian values or national identity, and extend across income groups and strength of British identity. Our group-based economic variables outperform standard income, household- and national-level economic evaluations, and provide insight into the relevant measures of economic voting that are needed in a specification of an economic vote for Brexit that can potentially be applied more generally.

This study offers a way to bridge existing explanations for Trump voting and Brexit voting that correlates geographically with various economic indicators (for example, Adler and Ansell 2020; Colantone and Stanig 2018; Fetzer 2019), but typically exhibits a stronger relationship at the individual level with concerns about immigration (Clarke, Goodwin and Whiteley 2017; Donovan and Redlawsk 2018; Goodwin and Milazzo 2017; Hobolt 2016; Iakhnis et al. 2018; Kaufmann 2016; Mutz 2018; Norris and Inglehart 2018; Schaffner, MacWilliams and Nteta 2018). More fundamentally, it moves us beyond an overly simplistic divide between the economy and immigration concerns as independent explanations, and beyond a variable race approach to assessing economic and cultural explanations. Our article combines economic and in/out group-based grievances, recognizing that cultural and economic factors are interdependent. In so doing, it helps to build bridges across perspectives in the wider populism literature and foster better crossdisciplinary understanding.

\section{Economic and racial grievances}

The literature identifies three grievances that typify the campaigns of populists: (1) those concerned with the economy; (2) those stemming from race, immigration and national identity and (3) those targeted at the political system (Ivarsflaten 2008). However, while the way in which populists try to win votes is accepted, the relative weight of these different grievances in voting for populism is the subject of 'a major debate about the drivers of populist appeal' (Adler and Ansell 2020, 2).

Economic explanations focus on the substantial changes in economic inequality and globalization that have taken place over time. These include the consequences of deindustrialization as well as the decline of domestic manufacturing, traditional industries and jobs, out-sourcing and increases in cheaper imports. These changes have been coupled with a rise in high-tech industries and markets to which lower-skilled manual workers cannot readily gain access. Prosperity has been concentrated in major metropolitan high-skilled areas (with higher-than-average proportions of graduates and minorities) at the expense of traditional industries and areas of the country 
that have been 'left behind' (Ford and Goodwin 2014). Conceived in this way, a vote for Donald Trump was - at least in part - a vote to restore American jobs and working-class status, and to revitalize parts of the country that were once the beneficiary of the manufacturing industry. Tankersley (2016) points to the importance of globalization, de-industrialization and inequalities in patterns of voting for Trump, and exposes regional and sub-regional differences between cities and suburban and rural towns. ${ }^{1}$ Similar patterns have been observed for the Brexit vote. Support for the Leave campaign followed a geographically uneven pattern that was consistent with the impacts of the economic and social consequences of globalization (Jennings and Stoker 2017). Colantone and Stanig (2018) show a relationship between support for Leave and Chinese import shocks, and Adler and Ansell (2020) reveal the importance of variations in wealth, captured by housing prices, on votes to leave the European Union (EU) and also on support for Marine Le Pen in France. Fetzer (2019; Fetzer, Becker and Novy 2018) finds that local variation in the outcomes of British austerity measures affected support for Leave.

However, while prior studies have demonstrated statistical relationships between localized economic variation and electoral behaviour, estimating economic effects at the individual level has been less conclusive. Surveys typically provide measures of egocentric economic conditions (the risk of losing a job, becoming unemployed, household economic circumstances) and measures of the national economy. Yet egocentric measures are unanchored in the larger context, while national performance indicators fail to capture people's perceptions about places and groups that enjoy economic prosperity and wealth, and those that have been 'left behind'. Cramer (2016), importantly, shows how local communities in parts of rural America compare perceptions of the fairness of government investment in cities (where deprivation and racial diversity is higher and where economic opportunity and prosperity also tends to be higher) with relatively smaller investments in rural towns and communities (where economic growth is weaker and economic opportunities fewer). Cramer demonstrates that people in those communities feel betrayed, as though unfair advantages paid for by their 'tax dollars' benefit other groups and areas. It follows that people see greater economic opportunities and gains in areas other than their own, and among some social groups in relation to their own. These perceptions drive political resentments.

Another economic explanation also points to the importance of social groups. Changes in the status of social classes and racial groups have arisen, in part, because of the changing nature of the economy over time. Hofstadter (1967) first argued that the American radical right emerged in response to perceived drops in, and threats to, social status. Olson $(2008,708)$ described whiteness as a status in the social hierarchy, 'a glass floor below which the white citizen could see but never fall'. Perceptions about the direction of relative economic gains and losses between groups implies a potential threat to social status, which in turn evokes feelings of hostility to out-groups (Tajfel 1978; Tajfel and Turner 1979). The impacts of deindustrialization and globalization on social status loss have been especially concentrated among working-class men without college degrees (Gidron and Hall 2017). These individuals tend to be more anti-elitist, anti-immigrant and anti-globalization. Gest (2016; Gest, Reny and Mayer 2018) also emphasizes the role of relative social status decline among white working-class men, particularly in relation to the economic status ascendance of ethnic minorities over time.

Group-based comparisons relate to the economic- and immigration-based grievances on which populists campaign. Populism evokes 'claims of speaking for "regular people" anxious about social, cultural and economic change that is often attributed to the presence and social ascendance of racial and ethnic minorities' (Donovan and Redlawsk 2018, 192). Populist appeals portray unfair economic benefits bestowed on migrants - such as access to housing, benefits, public services and jobs - and suggest that migrants benefit from unfair economic prosperity at the expense of white natives. The role of the economy and immigration become two sides of the

${ }^{1}$ https://www.washingtonpost.com/news/wonk/wp/2016/11/09/how-trump-won-the-revenge-of-working-class-whites/. 
impact of globalization, or of broader long-term social and economic change. Note that it is the perception of relative gains and losses that is crucial, and whether those relative gains and losses pass a person's threshold to motivate their political resentments or grievances. Many would strongly disagree with assertions that, across class classifications or economic sectors, minorities are afforded more (or too many) status and economic opportunities than the white native population.

If concerns about immigration are based partly on economic worries, it is methodologically difficult to separate concerns related to the economy, race, immigration and identity from possible economic sources of concern about immigration. Economic drivers of immigration sentiment and nativism arise in two distinguishable ways. The first is through economic competition, as minorities enter the workforce in greater numbers with increased migration over time and sector, which is consistent with realist inter-racial threat theory (Stephan and Renfro 2002; Stephan and Stephan 1985). Pardos-Prado and Xena (2019) find a link between skills-based economic competition and concerns about immigration, and Hays et al. (2019) maintain that import shocks produce a broad-based response at the regional level, which is mediated through xenophobic beliefs about immigrants and translated into populist support. Another arises due to the experience of economic distress. This is demonstrated by Carreras, Carreras and Bowler (2019), who show that long-term economic decline has led to a rise in resentment about immigration in Britain, which in turn motivated support for Brexit.

Nevertheless, the economic bases of immigration concerns are not without critique. Sniderman, Hagendoorn and Prior (2004) find that national identity, rather than economic advantage, leads to exclusionary reactions to ethnic minorities. Hainmueller and Hopkins (2014) similarly conclude that the bulk of scientific evidence suggests that the primacy of identity concerns, rather than the national economic effects of immigration, fuels anti-immigration attitudes. These studies support the view that people are concerned mostly about the cultural consequences of immigration. Analysis of the 2016 US presidential election finds overwhelming evidence of the importance of immigration- and race-related concerns and prejudices at the individual level, and only weak evidence of the role of the economy, operationalized in different ways (Donovan and Redlawsk 2018; Mutz 2018; Schaffner, MacWilliams and Nteta 2018). ${ }^{2}$ Norris and Inglehart (2018) discuss the predominant role of cultural threats in their explanation of populism, including in the votes for Trump and Brexit. While noting that economics had some effect on Brexit vote choice, the majority of individual-level evidence on the results of the referendum points to the dominant role of immigration concerns, alongside wider concerns about multiculturalism and cosmopolitanism (Clarke, Goodwin and Whiteley 2017; Goodwin and Milazzo 2017; Hobolt 2016; Iakhnis et al. 2018). As Kaufmann $(2016,2018)$ surmises, 'It's NOT the economy, stupid'. 3

Studies that focus on individual-level determinants of support for populist parties and causes tend to find that cultural drivers dominate, whereas analyses of local-level relationships reveal the importance of economic hardship and variation. One means of reconciling these contradictory findings points to an ecological fallacy: economic accounts supply strong evidence at the local level, but immigration does the bulk of explanatory work at the individual level. Another possible explanation is that local economic variation corresponds more strongly to individual-level immigration concerns due to relationships among economic experience, skills-based competition,

\footnotetext{
${ }^{2}$ German Lopez's framing of the debate in a December 2017 Vox article is representative. He writes, 'More than a year after President Donald Trump won the election, there are still some questions about what drove him to victory: Was it genuine anxiety about the state of the economy? Or was it racism and racial resentment?' Available from https:/www.vox.com/identities/ 2017/12/15/16781222/trump-racism-economic-anxiety-study.

${ }^{3}$ This is the title of Kaufman's (2016) blog: https://blogs.lse.ac.uk/politicsandpolicy/personal-values-brexit-vote/.
} 
economic and status loss, and attitudes about immigration. This means that any 'variable race' approach at the micro level will underestimate the indirect effects of economics. This has important implications. If economic and racial grievances are - at least in part - explained by economic inequalities, that highlights clear policy drivers and policy consequences. If such grievances are driven by racial resentment, the policy implications become targeted at the politicization of messages about race and immigration, which are concerned either with better integration or with slowing the pace of immigration.

A more promising explanation, we propose, is that voters focus less on their own economic fortunes and more on those of their communities, groups and people like themselves, and on the economic gains and relative losses of 'out-groups' (Kinder and Kam 2009). An important analytic step is therefore required. We need to measure economic conditions in a way that captures the relevant economic assessments - of groups and areas - that are argued to be important in an economic grievance explanation of populism. Specifically, an economic vote for populism should be conceptualized by a group-based economic vote.

\section{Who gets what: group-based winners and losers}

Groups provide an important way of organizing people's relevant perceptions about the economy. Voters do not only consider their own personal economic interests; they also take into account the national economy (Kinder and Kiewiet 1981), regional economic performance (Ansolabehere, Meredith and Snowberg 2014; Pattie and Johnston 1995), economic outcomes in local communities (Rogers 2014), and the relative gains and losses of groups. As Mutz and Mondak $(1997,286)$ put it, 'private economic experience is not, by itself, politically potent'; however, 'groups may serve as essential mediating entities, making it possible for people to politicize the economic interests of those like them without necessarily relying directly on personal economic experience'. Political decisions benefit the interests of different groups and areas; this is the very basis of political competition and representation (Thau 2019). Groups provide a way for voters to learn about the outcomes of government policy, a means through which voters can reward or punish a government for its advocacy for or against different groups, and they provide a heuristic for wider assessments. Voters evaluate the national economy, for example, based on information on the economic experiences of people like themselves (Ansolabehere, Meredith and Snowberg 2014).

In terms of driving resentments or grievances, group-based assessments and comparisons should matter in several ways relating to in-groups and out-groups (Kinder and Kam 2009). Individuals may primarily care about the gains or losses of a group to which they identity (the in-group), the gains or losses of a group to which they do not belong (an out-group), and/or the relative gains and losses of an out-group relative to an in-group. Social dominance theory predicts that some people have preferences for group-based dominance and social hierarchy - a preference for group-based inequalities maintained by hierarchy-enhancing ideologies and social policies (Ho et al. 2012; 2015; Mutz 2018; Sidanius and Pratto 1999). Social dominance orientation would predict opposition to affirmative action policies, which would be viewed as giving unfair economic advantages against a dominant group, and this increases when people feel threatened (Morrison and Ybarra 2008). When a group's status is threatened, it can respond with actions that seek to promote social change that preserves the existing hierarchy (Hogg and Abrams 1988).

Research on the economic sources of populism suggests that group-based resentments turn on ethnic and geographic comparisons in relation to racial and economic status (Cramer 2016; Gest 2016; Gest, Reny and Mayer 2018; Gidron and Hall 2017). Central to this is the notion of relative gains and losses. 'Because social status is based on a rank ordering, it is somewhat like a positional good, in the sense that, when many others acquire more status, the value of one's own status may decline' (Gidron and Hall 2017, 66). Zero-sum thinking predicts that if people perceive that some 
groups have enjoyed gains, they will believe other groups have experienced losses (Bobo and Hutchings 1996; Norton and Sommers 2011). It follows that if people perceive minorities to be gaining economically, some are also more likely to see the white majority doing relatively worse. The same may apply to geography: if one part of the country is perceived to be doing well, other areas are doing relatively worse. Tapping perceptions of group gains or losses over time, this relative group-based focus is different from relative economic inequalities between rich and poor, or of one's own finances vs. those of the national economy (Burgoon et al. 2019; Clarke, Goodwin and Whiteley 2017).

We consider the relative perceived gains and losses across relevant social groups. This relates to whether groups are doing better or worse than they were, rather than absolute comparisons, because we should be most interested in the relative direction of change. Such perceptions lead to politically potent resentments when voters are presented with options to revert to a previous economic and cultural status quo, epitomized in the 'Make America Great Again' rallying cry and the EU Leave campaign's slogan of 'Take Back Control'. These campaigns promise change for people who have experienced losses in their cultural and economic status. They increase awareness and information, and heighten people's perceptions of the relative gains and losses of groups, priming their salience for subsequent political choices. ${ }^{4}$

We apply these arguments and expectations to the campaign for Britain to leave the European Union (Brexit). Our argument predicts that support for Brexit will be higher if people perceive their in-group to be doing worse, when they perceive an out-group to be doing better over time, and when they perceive the out-group to be doing better relative to the in-group. Specifically, given the salience of immigration during the relevant period in British politics (Fieldhouse et al. 2019a), we expect Leave support to be predicted by perceptions that ethnic minorities are doing better economically, and by perceptions that white British people are doing less well relative to ethnic minorities. Furthermore, following the literature, we also expect Leave support to be predicted by perceptions that Londoners are doing relatively better than people in respondents' local communities (those outside London). We break this down into the following Group-Based Economics hypotheses.

Hypothesis 1: Negative economic assessments of a person's in-group predicts voting Leave in the EU referendum.

Hypothesis 2: Positive economic assessments of a person's out-group predicts voting Leave in the EU referendum.

Hypothesis 3: Negative economic assessments of a person's in-group relative to one's out-group predict voting Leave in the EU referendum.

\section{Measurement and methods}

We devised new survey questions which were fielded in the BES Internet Panel (Fieldhouse et al. 2019b). The group-based economic evaluations battery was asked in Wave 11, between 24 April and 3 May 2017. Along with standard items about the state of the national economy and personal finances, respondents were asked to evaluate the financial situation of social groups. These included 'white British people', 'ethnic minority immigrants', 'people in your local community' and 'people in London'. For each group, respondents assessed the group's current situation

\footnotetext{
${ }^{4}$ Note that this explanation does not need to be confined to populists if mainstream political campaigns also focus on restoring relative economic gains to certain social groups.
} 
compared to that of 12 months ago with responses categories of 'got a lot worse', 'got a little worse', 'stayed the same', 'got a little better' and 'got a lot better.'

Our primary focus is on group-based economic evaluations based on ethnicity. ${ }^{5}$ Figure 1 shows how economic perceptions vary across in-groups and out-groups, where $0=$ financial situation had 'got a lot worse' compared to 12 months ago, $1=$ 'got a lot better' and $0.5=$ 'stayed the same'. The group means are presented alongside views about national and personal economies. The sample is confined to white British respondents (93 per cent of the total sample); as such, 'white British people' are the in-group and 'ethnic minority immigrants' the out-group. Figure 1 shows that, overall, respondents hold negative perceptions. The most negative assessments are assigned to the nation as a whole and to white British people (the in-group), while views of one's own economy and, critically, the immigrant out-group, are viewed more positively.

From these variables we create a relative group-based economic perceptions measure by subtracting respondents' perceptions of ethnic minorities from those of white British people. People who evaluate the out-group financial performance identically to that of the in-group receive a value of 0 . Values greater than 0 indicate that the in-group has done better, and less than 0 where the out-group has done better. We also create the same comparisons for the respondent's own economic situation relative to the perceived economic situation of the out-group.

Table 1 reports the distribution of these responses (Appendix Table A1 provides details of the coding of these and other variables used in our analyses). Cells on the left-hand side compare personal financial perceptions with the ethnic minority out-group, and those on the right-hand side draw the in-group-out-group comparison. Perceptions vary widely. Most importantly, large shares of respondents evaluated the economic situation of the groups differently. If everyone assessed their own financial gains and those of the group identically, then the on-diagonal cells would sum to 100 per cent. Yet only 52 per cent assigned the same evaluations to ethnic minority immigrants as to themselves, and 58 per cent did so with respect to immigrants and 'white British people'.

Large shares of the population viewed one group as gaining and another losing. Fewer than 3 per cent replied that white British people and ethnic-minority immigrants were doing better. The majority believed that ethnic-minority immigrants were doing the same or better, compared to both self-ratings and ratings of white British people. Note that this is contrary to the facts, which show that ethnic minorities are doing worse. ${ }^{6}$

Our chief dependent variable is support for Britain's exit from the EU (Brexit). We use responses to the survey item 'If there was another referendum on EU membership, how do you think you would vote?' taken from BES panel Wave 11 to pair with the group economic evaluations items. Those who responded that they would vote Leave are coded 1 and Remain 0.

Comparing vote preferences to group economic perceptions lends initial support to the importance of relative group evaluations. Among white British people, respondents are equally likely to say they would choose Remain as they would to opt for Leave, at 46 per cent each. ${ }^{7}$ If we consider only white British respondents who believed the financial situation of ethnic minority out-groups had improved over the past year, then the share of Leavers increases to 56 per cent. Support for Brexit increases still more, to 68 per cent, among those in the latter group who also maintain that their own in-group of white British people had fared worse financially relative to 12 months previous. These survey marginals lend initial support to our group-based economic hypothesis (Hypothesis 3).

\footnotetext{
${ }^{5} \mathrm{We}$ undertook a series of tests to establish that there is sufficient distribution of economic assessments across the range of attitudes towards immigrants. None of our variables was correlated above 0.4. It is therefore not the case that people with negative views of immigrants necessarily think white British people are doing worse than ethnic minorities, or that people with positive views of immigrants believe ethnic minorities are doing worse than white British people.

${ }^{6}$ https://www.ethnicity-facts-figures.service.gov.uk/work-pay-and-benefits/pay-and-income/low-income/latest.

${ }^{7}$ This compares with 48 per cent Remain and 44 per cent Leave for the sample overall. The remaining 8 per cent of respondents responded 'don't know' or said they would not vote.
} 


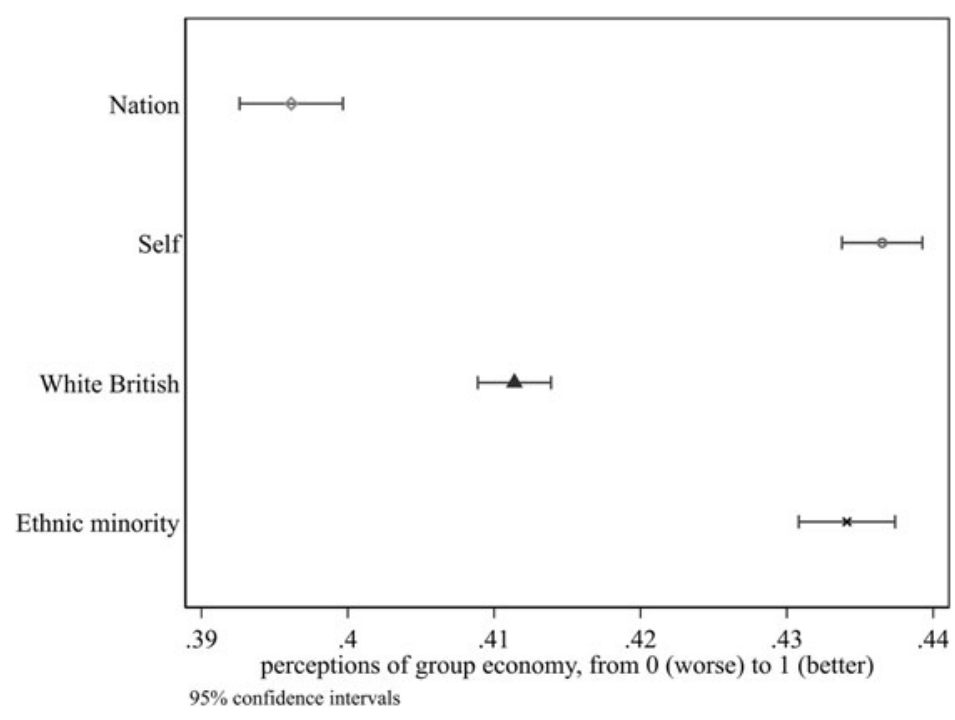

Figure 1. Retrospective evaluations of select groups

Note: the figure reports mean values of respondents on the economic evaluation item in question, where $0=$ got a lot worse, $0.5=$ stay the same, $1=$ got a lot better. White British respondents only.

Source: Fieldhouse et al. (2019b).

Table 1. Comparison of financial conditions of self and ethnic in-group with financial conditions of ethnic out-group

\begin{tabular}{|c|c|c|c|c|c|c|c|}
\hline \multirow{3}{*}{$\begin{array}{l}\text { Financial situation of } \\
\text { ethnic minority }\end{array}$} & \multirow[b]{3}{*}{ Worse } & \multicolumn{3}{|c|}{$\begin{array}{l}\text { (A) Financial situation of self } \\
\text { v. } 12 \text { months ago }\end{array}$} & \multicolumn{3}{|c|}{$\begin{array}{l}\text { (B) Financial situation of white } \\
\text { British people v. } 12 \text { months ago }\end{array}$} \\
\hline & & Worse & Same & Better & Worse & Same & Better \\
\hline & & 19.5 & 9.2 & 5.5 & 21.7 & 8.2 & 8.2 \\
\hline immigrants compared & Same & 15.8 & 29.2 & 7.5 & 14.2 & 34.2 & 5.8 \\
\hline to 12 months ago & Better & 3.7 & 6.0 & 3.5 & 2.4 & 2.7 & 2.7 \\
\hline
\end{tabular}

Note: cells report the percent that evaluated the groups according to the combinations of worse, same and better. Shaded cells highlight the on-diagonal values which together sum to lower than 100. Ethnic white British respondents only. $N$ for comparison to self $=20,782 ; N$ for comparison to white British people $=20,117$.

Source: Fieldhouse et al. (2019b).

We use the panel structure of the data to address sources of bias owing to response endogeneity. Models include the respondent's prior vote in the EU referendum. For most respondents this comes from Wave 9 (immediately after the referendum in June 2016), but for those new to the panel in Waves 10 and 11, this variable represents the earliest available recall measure. ${ }^{8}$ Including 2016 EU referendum vote controls for the possibility that preferences about Brexit - and corresponding beliefs about the group-based economic outcomes of Brexit - lead to perceptions of group-based gains and losses. ${ }^{9}$ If this endogeneity were to exist, and for any bias to lead to findings that could explain our hypothesized expectations, Leave voters would need to believe that ethnic minorities were doing better and white British worse as a result of Brexit, whereas we suggest that the reverse should be the case. Also, to isolate the influence of group-based evaluations, we include standard retrospective national economic perceptions.

We include a set of additional variables to address alternative explanations. We capture immigration attitudes using answers to the question 'Do you think that immigration undermines or

\footnotetext{
${ }^{8}$ Further information about the dataset is available from: https://www.britishelectionstudy.com/wp-content/uploads/2019/ 06/Bes_wave15Documentation_V2.pdf.

${ }^{9}$ Comparing national and household retrospective economic evaluations for Leave and Remain voters prior (in Wave 7) and after the referendum (Wave 11) shows that evaluations diverge, but only significantly on the national economy, and then only at a magnitude of just 0.07 points, on average, across the full $0-1$ scale. See Appendix Figure A1.
} 
enriches Britain's cultural life? ${ }^{10}$ This item, Anti-immigration Sentiment, controls for attitudes that could be downstream of economic evaluations of different groups and, hence, provides a strict test of our expectations. To account for general feelings of ethnic identity, models include British National Sentiment, produced by combining responses to five items (Heath et al. 1999), as well as Authoritarianism - tapping authoritarian tendencies identified as an antecedent of intergroup threat (Altemeyer 1981; Heath, Evans and Martin 1994). To avoid bias arising from posttreatment measurement (Montgomery, Nyhan and Torres 2018), each of these control variables is measured in previous waves. Models also include demographic items: age, gender, education level, income. All controls are rescaled to $0-1$. Table A1 provides all details and A2 the descriptive properties for each variable.

To assess the effects of group economic performance on Brexit support, we regress referendum vote intention on economic evaluations of in-groups and out-groups. Our statistical models are of the form:

$$
\operatorname{prob}\left(Y_{i t}=1\right)=\alpha+\delta Y_{i, t-1}+\beta E_{i t}+\sum \gamma_{j} C_{i j, t-1}+\sum \lambda_{k} D_{i k t}+\varepsilon_{i t}
$$

where $Y_{i t}$ is Brexit support for individual $i$ at wave $t, Y_{i t-1}$ is past Brexit support in the form of reported vote asked in the post-referendum wave, and $E_{i t}$ is $i$ 's retrospective economic perceptions measured at wave $t .{ }^{11}$ Control variables are of two types: $C_{i j, t-1}$ is a set of $j$ cultural variables tapping immigration attitudes, authoritarianism and British national sentiment measured in previous waves, and $D_{i k, t}$ is a set of $k$ demographic attributes for age, gender, education and income.

Table 2 reports the results. Model 1 is a baseline specification that examines the influence of the respondent's own personal financial situation, as commonplace. In place of personal finances, Model 2 includes perceptions of the financial situation of white British people. The coefficient is imprecisely estimated: for white Britons, perceptions of in-group economic standing - on its own - does not shape positions on Brexit. Model 3, however, implies that out-group economic perceptions do matter: those who perceive that the economic status of the out-group has improved are substantially more likely to vote Leave. Model 4 shows that this finding is robust to the inclusion of in-group perceptions, and is indeed driven primarily by out-group perceptions, rather than the relative evaluations of in-groups and out-groups (see Arel-Bundock, Blais and Dassonneville 2020). ${ }^{12}$ Model 5 shows that the relative measure of in-group and out-group economic evaluations is significant when modelled on its own. The negatively signed coefficient indicates that support for Leave is greater among those who report that the economic situation of white British people is worse relative to the ethnic-minority immigrant out-group. All of these effects are replicated in models that do not control for the lagged dependent variable (see Table A3).

Table 2 (Model 4) and Figure 2 demonstrate that a large part of this effect is driven by the economic evaluation of the out-group - in this case, the economic evaluations of ethnic minorities. Figure 2 summarizes the results from Table 2 using predicted probabilities. We see that when taken alone, perceptions of one's own financial situation and one's in-group have no bearing on support for Brexit. The latter non-finding suggests a failure to support Hypothesis 1. However, consistent with Hypothesis 2, Figure 2c shows that economic conditions have an impact when compiled in terms of the out-group's performance (Figure 2c). Furthermore, this

\footnotetext{
${ }^{10}$ Using an alternative immigration measure that assesses whether immigration is good or bad for the economy, or a combination of these measures, has no bearing on the results.

${ }^{11}$ Following previous studies of economic voting using panel data, retrospective economic assessments are entered into the model contemporaneously with the outcome variable. As Lewis-Beck, Nadeau and Elias $(2008,87)$ note, 'it makes little theoretical sense to lag economic retrospections, since it is a measure of how the economy performed over the past year'. See also Evans and Andersen (2006). We nonetheless re-ran models with the dependent variable taken from the subsequent June 2017 panel wave, retaining all right-hand-side variables in Table 2. The results are unchanged.

${ }^{12}$ Appendix Table A3 demonstrates that both coefficients are statistically significant when we do not control for past EU referendum vote. The same is the case for Tables A7 and A8, discussed below.
} 
Table 2. The effects of economic perceptions on referendum vote intentions, April-May 2017

\begin{tabular}{|c|c|c|c|c|c|}
\hline & M1 & M2 & M3 & M4 & M5 \\
\hline 2016 EU Referendum vote ${ }_{t-1}$ & $\begin{array}{l}5.19^{\star \star} \\
(0.11)\end{array}$ & $\begin{array}{l}5.14^{\star \star} \\
(0.12)\end{array}$ & $\begin{array}{l}5.17^{\star \star} \\
(0.12)\end{array}$ & $\begin{array}{l}5.17^{\star \star} \\
(0.13)\end{array}$ & $\begin{array}{l}5.16^{\star \star} \\
(0.12)\end{array}$ \\
\hline Self-economy ${ }_{t}$ & $\begin{array}{c}0.18 \\
(0.26)\end{array}$ & & & & \\
\hline In-Group economy ${ }_{t}$ & & $\begin{array}{c}-0.13 \\
(0.32)\end{array}$ & & $\begin{array}{c}-0.42 \\
(0.36)\end{array}$ & \\
\hline Out-Group economy $t$ & & & $\begin{array}{l}1.76^{\star \star} \\
(0.29)\end{array}$ & $\begin{array}{l}1.83^{\star \star} \\
(0.30)\end{array}$ & \\
\hline In-Group v. Out-Group $t$ & & & & & $\begin{array}{c}-1.31^{\star *} \\
(0.26)\end{array}$ \\
\hline National economy $t_{t}$ & $\begin{array}{l}2.78^{\star \star} \\
(0.24)\end{array}$ & $\begin{array}{l}2.89^{\star *} \\
(0.24)\end{array}$ & $\begin{array}{l}2.33^{\star \star} \\
(0.25)\end{array}$ & $\begin{array}{l}2.51^{\star \star} \\
(0.26)\end{array}$ & $\begin{array}{l}2.85^{\star \star} \\
(0.25)\end{array}$ \\
\hline Anti-immig. sentiment $t_{t-1}$ & $\begin{array}{l}1.29^{\star *} \\
(0.20)\end{array}$ & $\begin{array}{l}1.30^{* *} \\
(0.21)\end{array}$ & $\begin{array}{l}1.10^{\star *} \\
(0.22)\end{array}$ & $\begin{array}{l}1.08^{\star \star} \\
(0.22)\end{array}$ & $\begin{array}{l}1.07^{\star *} \\
(0.22)\end{array}$ \\
\hline British nat. sentiment $_{t-1}$ & $\begin{array}{l}1.65^{\star *} \\
(0.25)\end{array}$ & $\begin{array}{l}1.68^{\star \star} \\
(0.26)\end{array}$ & $\begin{array}{l}1.92^{\star \star} \\
(0.29)\end{array}$ & $\begin{array}{l}1.89^{\star \star} \\
(0.30)\end{array}$ & $\begin{array}{l}1.96^{\star *} \\
(0.30)\end{array}$ \\
\hline Authoritarianism $_{t-1}$ & $\begin{array}{c}0.29 \\
(0.37)\end{array}$ & $\begin{array}{c}0.23 \\
(0.39)\end{array}$ & $\begin{array}{c}-0.00 \\
(0.42)\end{array}$ & $\begin{array}{c}-0.08 \\
(0.43)\end{array}$ & $\begin{array}{c}-0.01 \\
(0.43)\end{array}$ \\
\hline Age $_{t}$ & $\begin{array}{c}0.54 \\
(0.31)\end{array}$ & $\begin{array}{c}0.35 \\
(0.32)\end{array}$ & $\begin{array}{c}0.49 \\
(0.35)\end{array}$ & $\begin{array}{c}0.36 \\
(0.36)\end{array}$ & $\begin{array}{c}0.29 \\
(0.36)\end{array}$ \\
\hline Female $_{t}$ & $\begin{array}{c}-0.01 \\
(0.10)\end{array}$ & $\begin{array}{c}-0.02 \\
(0.11)\end{array}$ & $\begin{array}{c}-0.01 \\
(0.12)\end{array}$ & $\begin{array}{c}-0.02 \\
(0.12)\end{array}$ & $\begin{array}{c}-0.02 \\
(0.12)\end{array}$ \\
\hline Education $_{t}$ & $\begin{array}{c}-0.62^{\star *} \\
(0.23)\end{array}$ & $\begin{array}{r}-0.61^{\star} \\
(0.24)\end{array}$ & $\begin{array}{c}-0.69^{\star \star} \\
(0.26)\end{array}$ & $\begin{array}{c}-0.69^{\star \star} \\
(0.27)\end{array}$ & $\begin{array}{c}-0.70^{\star \star} \\
(0.27)\end{array}$ \\
\hline Income $_{t}$ & $\begin{array}{r}-0.52^{\star} \\
(0.23)\end{array}$ & $\begin{array}{r}-0.53^{*} \\
(0.23)\end{array}$ & $\begin{array}{c}-0.46 \\
(0.25)\end{array}$ & $\begin{array}{c}-0.43 \\
(0.25)\end{array}$ & $\begin{array}{c}-0.42 \\
(0.25)\end{array}$ \\
\hline Constant & $\begin{array}{c}-5.09^{\star \star} \\
(0.42)\end{array}$ & $\begin{array}{c}-4.85^{\star \star} \\
(0.44)\end{array}$ & $\begin{array}{c}-5.40^{\star \star} \\
(0.47)\end{array}$ & $\begin{array}{c}-5.19^{\star \star} \\
(0.49)\end{array}$ & $\begin{array}{c}-4.75^{\star \star} \\
(0.48)\end{array}$ \\
\hline$N$ & 11,672 & 10,605 & 9,595 & 9,323 & 9,323 \\
\hline Log Likelihood & $-1,864.31$ & $-1,712.95$ & $-1,486.57$ & $-1,450.39$ & $-1,457.02$ \\
\hline Pseudo $R^{2}$ & 0.73 & 0.72 & 0.73 & 0.73 & 0.73 \\
\hline
\end{tabular}

Notes: cells report logit coefficients with standard errors in parentheses; $1=$ Leave, $0=$ Remain. White British respondents only. Weighted by weight_w10w11. ${ }^{\star \star} \mathrm{p}<0.01,{ }^{\star} \mathrm{p}<0.05$, two-tailed test

Source: Fieldhouse et al. (2019b).

effect is strongest when assessed relative to in-group performance perceptions (2D), as Hypothesis 3 predicts. We next draw further on the BES panel to assess the robustness of the results, and to examine potential extensions.

\section{Relative Group-Based Economics and Immigration Attitudes}

We take three additional steps to ensure that our group-based economics results do not merely stand in for views toward immigrants. We first examine whether relative group-based economics effects differ according to immigration attitudes. We do this by re-estimating Table 2 Model 5, conditioning the influence of perceptions of in-group-out-group economics on views of immigrants using an interaction between in-out group economic comparisons and immigration attitudes. ${ }^{13}$ Figure 3 shows that people with high levels of animosity towards immigrants $($ Anti-immig $=1)$ tend to be more likely to support Leave (in contrast to Anti-immig $=0)$. More importantly, the effect of relative group-based economic perceptions holds even for those with high levels of anti-immigration sentiment. This underlines the presence of relative group-based economic voting above and beyond existing immigration attitudes.

We next analyse, using multiple waves of the BES panel, the impacts of group-based economics on immigration attitudes nearly two years later. We regress immigration attitudes measured in April 2019 (BES panel Wave 15) on Wave 11 immigration attitudes and Wave 11 relative group-

\footnotetext{
${ }^{13}$ Appendix Table A4 reports parameter estimates.
} 

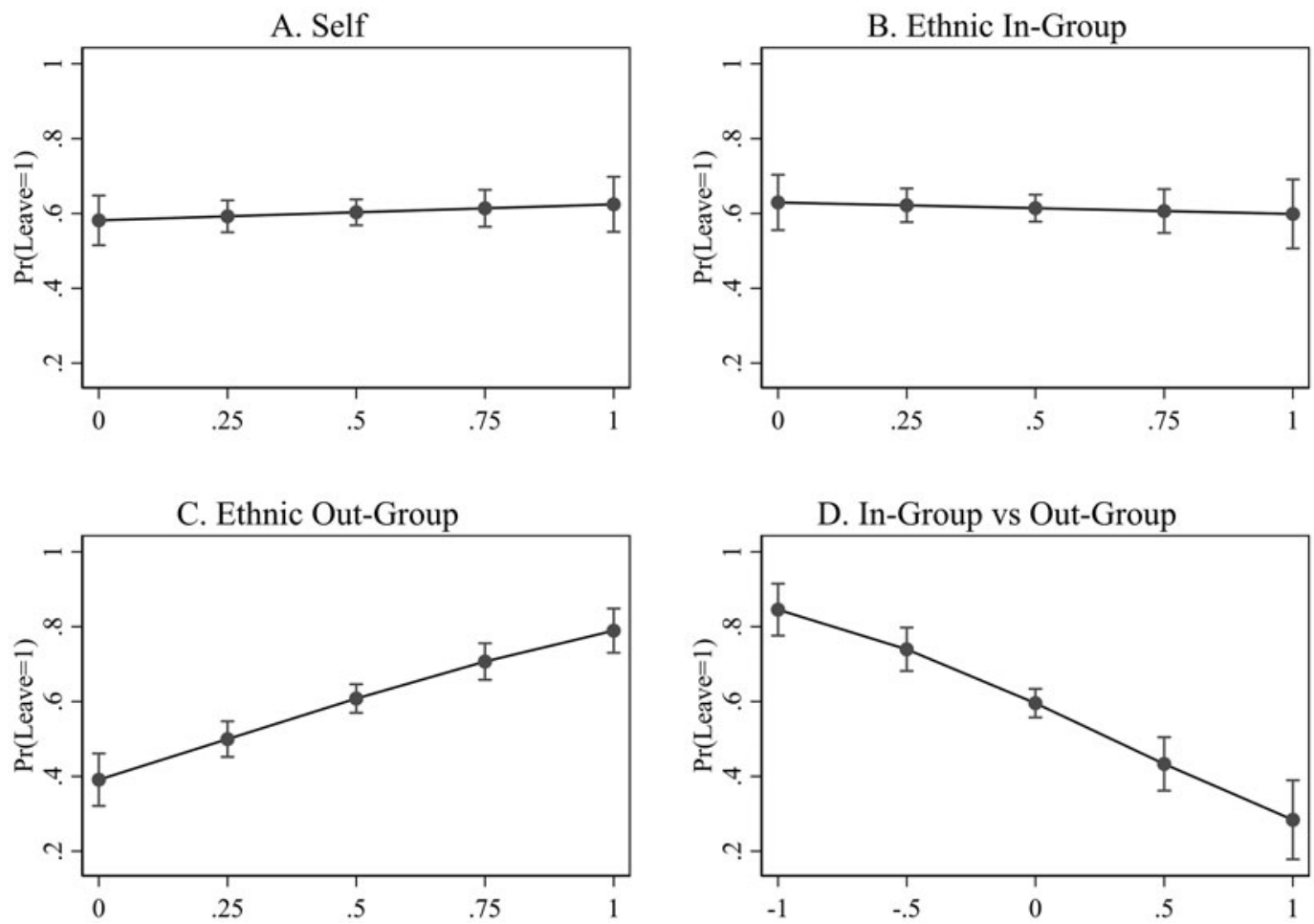

Figure 2. Predicted probability of supporting Leave in hypothetical referendum by ethnic group economic evaluations, April-May 2017

Notes: graphs report predicted probabilities using model estimates from Table 2. Vertical axes report the probability that the respondent would vote Leave in another referendum. Horizontal axes display economic perceptions, from 'got a lot worse' (0) to 'got a lot better' (1). Economic perceptions items are manipulated with all other variables held to their sample means or modes. Graphs A, B, C, and D are produced using estimates from Table 2 Models 1, 2, 3 and 5, respectively.

based economics variables. If evaluations of group-based economic gains were fully endogenous to general views of immigrants, the former should have no effect on the latter when we control for previous views of immigrants. This, however, is not the case: coefficients are precisely estimated for self vs. out-group and for in-group vs. out-group. Perceptions of group economic standing are conceptually separate from views of immigrants (see Table A5).

We also examine possible question-order effects by randomizing our survey instrument. The concept of ethnocentrism implies that people perceive themselves to be superior to out-groups (Kinder and Kam 2009). This may lead people to bias their in-group evaluations, or evaluations of 'self if asked to first assess the economic conditions of 'inferior' out-groups, akin to positive distinctiveness strategies predicted by social identity theory (Tajfel and Turner 1979). This could bias the results if people maximized in- and out-group differences in response to survey order effects. We therefore compared responses of white British respondents to the three key economic evaluation questions (self, ethnic in-group and ethnic out-group) according to whether they received the question relating to (a) self before out-group and (b) in-group before out-group. There were no significant differences in evaluations of white Britons based on question ordering (see Figure A2a). However, those asked about white Britons first scored minorities as having performed better economically than those that were asked about ethnic minorities first (Figure A2b). The differences are small on a five-point scale but are reflected in a greater negative difference score among respondents who were asked the in-group question first $(\operatorname{Pr}(T<t)=0.9996)$. When we split the sample by Leave and Remain voters, we see that the relationship is driven 


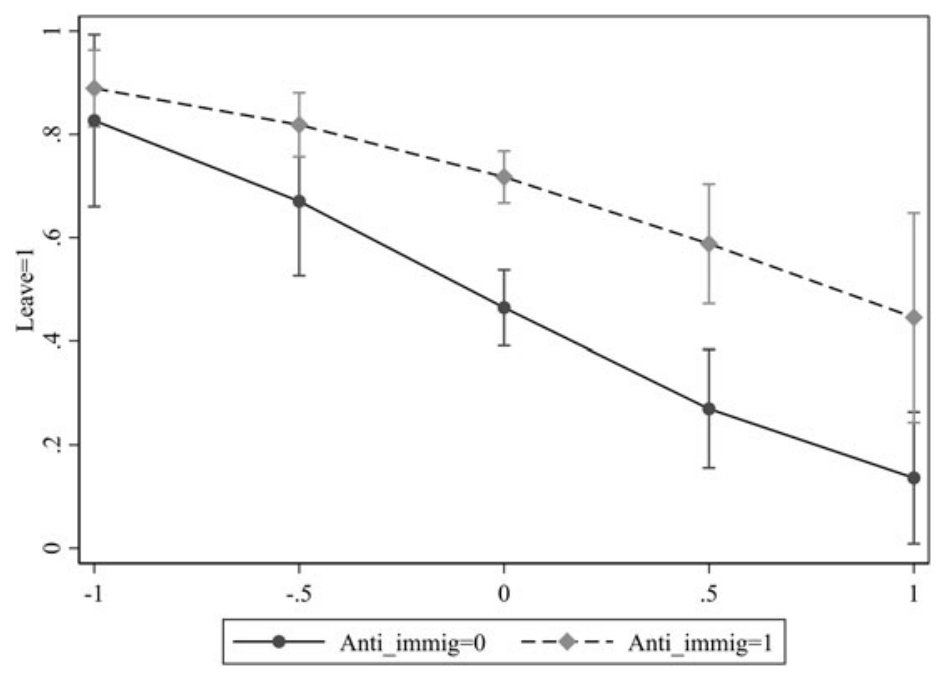

Figure 3. The effect of relative economic perceptions on referendum vote intentions for different levels of anti-immigration sentiment Notes: figure reports predicted probabilities of selecting Leave for those with low (solid line) and high (dashed line) values on Anti-immigration sentiment using model estimates from Appendix Table A4. Horizontal axes report values on in-group vs. out-group. Vertical bars report 95 per cent confidence intervals.

entirely by Leave voters (see Figure A3). This negative accentuation is opposite to what might be predicted by positive distinctiveness strategies of social identity theory. However, such downplaying of one's in-group is consistent with the interpretation that negative relative economic evaluations are an expression of resentment or perceived threat. To account for these modest effects, we included question order dummy variables in our models and found no change in the results reported above (Appendix Table A6 and Figure A4).

\section{Extensions of the Results}

We replicated our analyses with two alternative dependent variables: feelings toward Brexit (higher values for 'happy' the UK voted to leave EU; lower values for 'disappointed') and a factor score produced from five items tapping populist attitudes. Models estimated using ordinary least squares are reported in Appendix Tables A7 and A8 with predictions displayed in Figures A5 and A6. The results closely align with models in Table 2 and Figure 2, and reveal that out-group and in-group perceptions contribute to these political attitudes. These findings suggest that our argument is applicable to other cases in which populism sentiment is the outcome of interest and are not driven by the hypothetical nature of EU referendum vote intention after the Brexit referendum in 2016.

We also consider whether relative group-based economics is more important among lowincome respondents. Status threat and economic grievance explanations are argued to be especially relevant to lower-income groups - such as the white working class - whose prior social status had been higher and more secure (Gest 2016; Gest, Reny and Mayer 2018; Gidron and Hall 2017). We examine whether relative group-based economics are more important to Brexit support by variation in household income. Figure 4a reports the findings, which are based on further interactions re-estimating Table 2, Model 5. ${ }^{14}$ Those with below-average incomes (defined as the sample mean minus one standard deviation) are more likely to vote Leave relative to high incomes (mean plus one standard deviation). However, overlapping confidence intervals show that this effect is very modest. As the steep slopes for both lines show, far more important are the perceived economic gains made by minority out-groups relative to the white British in-group.

Furthermore, we re-ran our models including British identity strength to assess whether relative group-based assessments have greater weight for people with a stronger sense of Britishness.

\footnotetext{
${ }^{14}$ Parameter estimates are reported in Table A3, Model 2.
} 

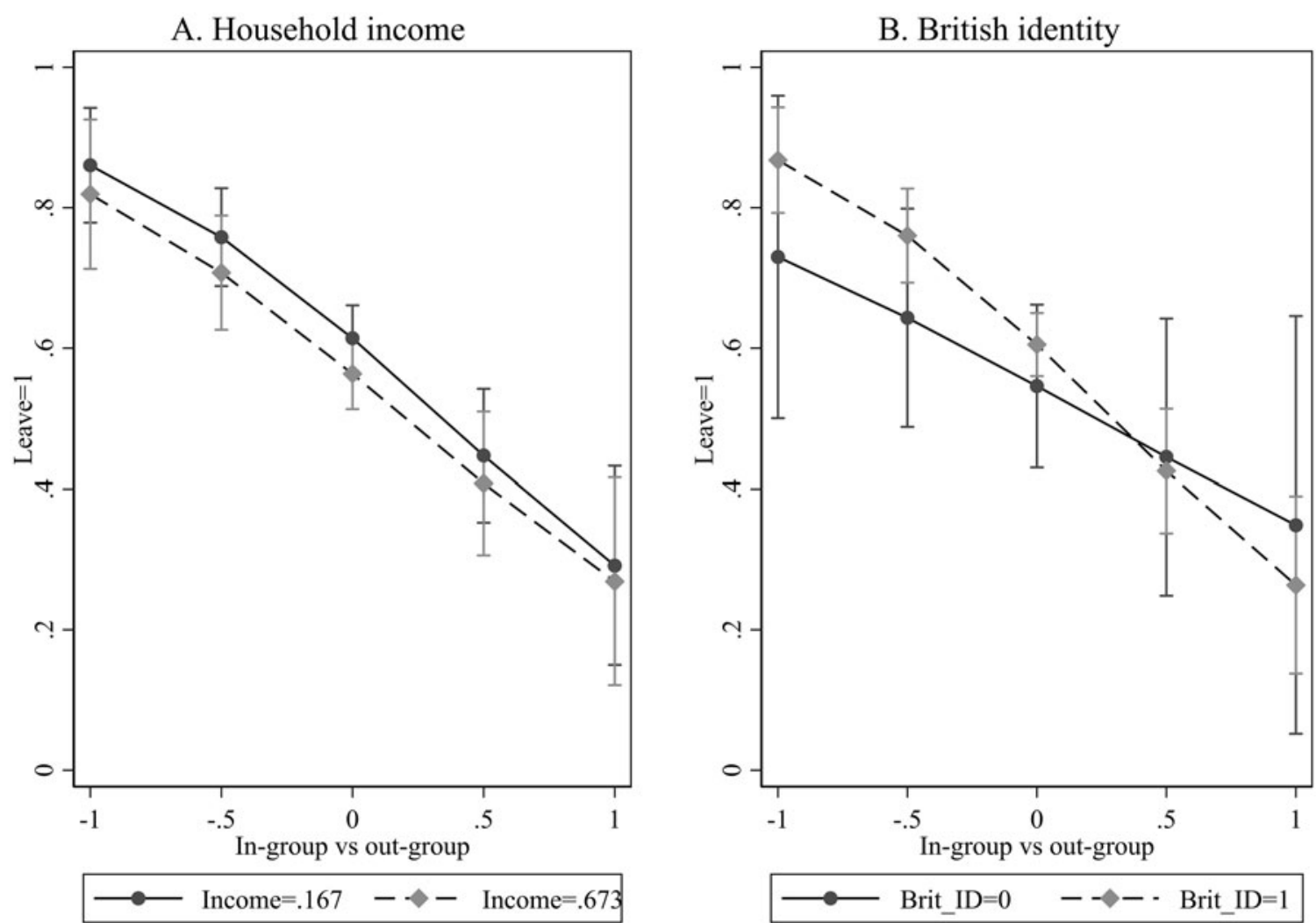

$\overrightarrow{0}$
0
0
$\mathbb{0}$
$\mathbb{0}$
0
0
0

Figure 4. The effect of relative economic perceptions on referendum vote intentions conditioned on household income and British identity

Notes: figure report predicted probabilities using model estimates from Columns 2 and 3 of Appendix Table A4. Panel A reports the same for those with low (solid line) and high (dashed line) values on household income, where values are set to the sample mean \pm 1 standard deviation. Panel B reports the expected probability of supporting Leave for those with low (solid line) and high (dashed line) values on British identity. Horizontal axes report values on in-group vs. out-group. Vertical bars report 95 per cent confidence intervals. 
If strength of attachment to the in-group accounts for the strength of group-based voting, then the impact of relative group perceptions might be stronger as a product of the strength of in-group identity. Figure $4 \mathrm{~b}$ shows that the effects were marginally (but not significantly) stronger for people without a strong British identity (see also Table A4). This is likely to be a compression effect (Berry, DeMeritt and Esarey 2010) since those with a strong British identity are already highly likely to support Brexit. ${ }^{15}$

\section{Group-based economics: geography}

If our theory is persuasive, it should extend beyond racial groups, including to groups for which evaluations do not just relate to socially dominant groups that are performing less well (that is, white British). As discussed, social dominance theory predicts that certain people have preferences for inequalities between groups, as long as dominant groups are more successful.

Geography plays a prominent role in current debates about the winners and losers in advanced capitalist societies, with urban centres gaining at the expense of rural communities. Accordingly, we replicate the analysis by comparing one's own position and the economic gains/losses of respondents' local communities (the in-group) with the economic gains and losses of those living in London (the out-group), Britain's political and financial capitol, modelling the sample excluding people living in London.

Table 3 reports the distribution of responses. Cells on the left-hand side compare personal financial perceptions with those of the Londoner out-group, and those on the right-hand side draw the in-group-out-group comparison. The majority of respondents think Londoners have fared better relative to both themselves and to people in their own communities. These differences correlate with support for Brexit. Among those perceiving their local community's economy to have improved but the London economy to have declined, 44 per cent supported Leave. By contrast, six in ten of those who viewed London's economy as faring better while their local community's had declined supported Brexit.

Table 4, Models 1-5 displays logistic regression model estimates. To better isolate the geographic differences from what may be construed as ethnic differences between London and elsewhere, we include the white British economy vs. ethnic minority difference measure from the last model in Table 2. At first blush, the results diverge from those for group effects in terms of ethnicity. The coefficient on the geographic in-group, Local Economy, is positively signed, indicating more positive in-group economic assessments among Leave supporters, rather than negative assessments, as Hypothesis 1 predicts. Model 5 shows that this persists for the local economy relative to the London economy, albeit weaker in magnitude.

Table 3 may provide an explanation for these counterintuitive results. The last column in the table shows that only 7 per cent of respondents evaluated their local economy as having gotten better; of that group, fewer than 1 per cent offered 'a lot better'. Our measures for Local Economy and its difference from London Economy are sharply skewed. We therefore re-estimate the model but create a series of dummy variables indicating whether the respondent viewed the performance of their local economy and the London economies as simply 'better' or 'worse' than 12 months previous (Table 4, Model 6). This creates four dummy variables with a reference category of 'stay the same' for at least one of the two groups. From these estimates, we calculate the probability of supporting Leave for each of the four combinations of perceptions. These predicted probabilities, displayed in Table 5, show that support for Leave is highest (probability 0.76) among those who

\footnotetext{
${ }^{15}$ To control for perceptions of the benefits and cultural ascendancy of minorities, we also examined perceptions that ethnic minorities were being discriminated in favour of relative to discriminated against. The question asks 'How much discrimination to you think there is in favour or against the following groups: black and minority ethnic' (asked in Wave 10 of the BES panel). Not surprisingly, we find that beliefs in such discrimination reduce the likelihood of supporting Brexit. Our relationships of interest remain unchanged.
} 
Table 3. Comparison of financial conditions of self and geographic in-group with financial conditions of geographic out-group

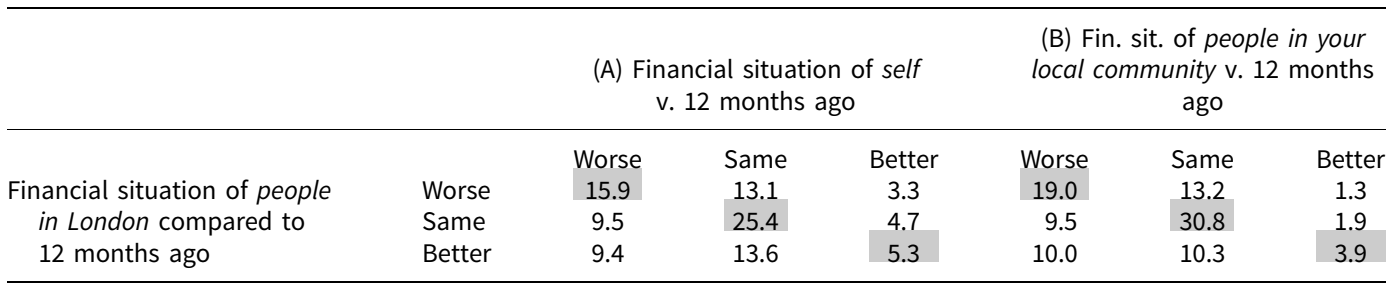

Note: cells report the percent who evaluate the groups according to the combinations of worse, same and better. Shaded cells highlight the on-diagonal values which together sum to lower than 100 . London residents excluded. $N$ for comparison to self $=20,782 ; N$ for comparison to people in local community $=19,035$.

Table 4. The effects of perceptions of local community and London economies on referendum vote intentions, April-May 2019

\begin{tabular}{|c|c|c|c|c|c|c|}
\hline & M1 & M2 & M3 & M4 & M5 & M6 \\
\hline 2016 EU Referendum vote ve $_{t-1}$ & $\begin{array}{l}5.15^{\star \star} \\
(0.13)\end{array}$ & $\begin{array}{l}5.17^{\star \star} \\
(0.13)\end{array}$ & $\begin{array}{l}5.13^{\star \star} \\
(0.13)\end{array}$ & $\begin{array}{l}5.16^{\star \star} \\
(0.14)\end{array}$ & $\begin{array}{l}5.16^{\star \star} \\
(0.14)\end{array}$ & $\begin{array}{l}5.19^{\star *} \\
(0.13)\end{array}$ \\
\hline Self-economy $t_{t}$ & $\begin{array}{c}0.59 \\
(0.33)\end{array}$ & & & & & \\
\hline Local economy $t_{t}$ & & $\begin{array}{l}1.42^{\star \star} \\
(0.41)\end{array}$ & & $\begin{array}{l}1.58^{\star *} \\
(0.43)\end{array}$ & & \\
\hline London economy $t_{t}$ & & & $\begin{array}{c}-0.08 \\
(0.27)\end{array}$ & $\begin{array}{c}-0.28 \\
(0.27)\end{array}$ & & \\
\hline Local econ. v. London econ.t & & & & & $\begin{array}{l}0.64^{\star \star} \\
(0.25)\end{array}$ & \\
\hline Local better London better ${ }_{t}$ & & & & & & $\begin{array}{c}-0.03 \\
(0.27)\end{array}$ \\
\hline Local better London worse $_{t}$ & & & & & & $\begin{array}{l}-0.75^{\star *} \\
(0.22)\end{array}$ \\
\hline Local worse London better $_{t}$ & & & & & & $\begin{array}{c}0.65 \\
(0.63)\end{array}$ \\
\hline Local worse London worse ${ }_{t}$ & & & & & & $\begin{array}{l}-0.54^{* *} \\
(0.18)\end{array}$ \\
\hline National economy $t_{t}$ & $\begin{array}{l}2.65^{\star \star} \\
(0.26)\end{array}$ & $\begin{array}{l}2.38^{\star \star} \\
(0.27)\end{array}$ & $\begin{array}{l}2.90^{\star \star} \\
(0.26)\end{array}$ & $\begin{array}{l}2.46^{\star \star} \\
(0.27)\end{array}$ & $\begin{array}{l}2.76^{\star \star} \\
(0.27)\end{array}$ & $\begin{array}{l}2.43^{\star \star} \\
(0.26)\end{array}$ \\
\hline Anti-immig. sentiment $t_{t-1}$ & $\begin{array}{l}1.13^{\star \star} \\
(0.23)\end{array}$ & $\begin{array}{l}1.10^{\star \star} \\
(0.24)\end{array}$ & $\begin{array}{l}1.07^{\star \star} \\
(0.24)\end{array}$ & $\begin{array}{l}1.07^{\star \star} \\
(0.25)\end{array}$ & $\begin{array}{l}1.07^{\star \star} \\
(0.25)\end{array}$ & $\begin{array}{l}1.07^{\star \star} \\
(0.24)\end{array}$ \\
\hline British nat. sentiment $t_{t-1}$ & $\begin{array}{l}1.92^{\star \star} \\
(0.32)\end{array}$ & $\begin{array}{l}1.93^{\star \star} \\
(0.33)\end{array}$ & $\begin{array}{l}1.88^{\star \star} \\
(0.34)\end{array}$ & $\begin{array}{l}1.86^{\star \star} \\
(0.35)\end{array}$ & $\begin{array}{l}1.91^{\star \star} \\
(0.34)\end{array}$ & $\begin{array}{l}1.94^{\star *} \\
(0.33)\end{array}$ \\
\hline Authoritarianism $_{t-1}$ & $\begin{array}{l}-0.08 \\
(0.45)\end{array}$ & $\begin{array}{c}-0.09 \\
(0.46)\end{array}$ & $\begin{array}{c}-0.14 \\
(0.46)\end{array}$ & $\begin{array}{c}-0.16 \\
(0.47)\end{array}$ & $\begin{array}{c}-0.10 \\
(0.48)\end{array}$ & $\begin{array}{c}-0.05 \\
(0.46)\end{array}$ \\
\hline Age $_{t}$ & $\begin{array}{c}0.44 \\
(0.37)\end{array}$ & $\begin{array}{c}0.49 \\
(0.39)\end{array}$ & $\begin{array}{c}0.42 \\
(0.39)\end{array}$ & $\begin{array}{c}0.50 \\
(0.40)\end{array}$ & $\begin{array}{c}0.46 \\
(0.40)\end{array}$ & $\begin{array}{c}0.51 \\
(0.38)\end{array}$ \\
\hline Female $_{t}$ & $\begin{array}{c}0.02 \\
(0.12)\end{array}$ & $\begin{array}{c}0.00 \\
(0.12)\end{array}$ & $\begin{array}{c}-0.04 \\
(0.13)\end{array}$ & $\begin{array}{c}-0.04 \\
(0.13)\end{array}$ & $\begin{array}{c}-0.06 \\
(0.13)\end{array}$ & $\begin{array}{c}-0.02 \\
(0.12)\end{array}$ \\
\hline Education $_{t}$ & $\begin{array}{r}-0.56^{*} \\
(0.27)\end{array}$ & $\begin{array}{c}-0.51 \\
(0.27)\end{array}$ & $\begin{array}{r}-0.58^{*} \\
(0.28)\end{array}$ & $\begin{array}{c}-0.52 \\
(0.28)\end{array}$ & $\begin{array}{c}-0.53 \\
(0.28)\end{array}$ & $\begin{array}{c}-0.50 \\
(0.27)\end{array}$ \\
\hline Income $_{t}$ & $\begin{array}{r}-0.53^{*} \\
(0.27)\end{array}$ & $\begin{array}{r}-0.56^{*} \\
(0.27)\end{array}$ & $\begin{array}{r}-0.54^{\star} \\
(0.27)\end{array}$ & $\begin{array}{r}-0.60^{*} \\
(0.28)\end{array}$ & $\begin{array}{r}-0.58^{*} \\
(0.28)\end{array}$ & $\begin{array}{r}-0.57^{\star} \\
(0.28)\end{array}$ \\
\hline Ethnic in-group v. out-group ${ }_{t}$ & $\begin{array}{c}-1.40^{\star \star} \\
(0.28)\end{array}$ & $\begin{array}{c}-1.45^{\star \star} \\
(0.27)\end{array}$ & $\begin{array}{c}-1.31^{\star \star} \\
(0.29)\end{array}$ & $\begin{array}{c}-1.48^{\star \star} \\
(0.29)\end{array}$ & $\begin{array}{c}-1.39^{\star \star} \\
(0.29)\end{array}$ & $\begin{array}{c}-1.44^{\star \star} \\
(0.27)\end{array}$ \\
\hline Constant & $\begin{array}{c}-5.04^{\star \star} \\
(0.52)\end{array}$ & $\begin{array}{c}-5.31^{\star \star} \\
(0.53)\end{array}$ & $\begin{array}{c}-4.67^{\star \star} \\
(0.54)\end{array}$ & $\begin{array}{c}-5.12^{\star \star} \\
(0.56)\end{array}$ & $\begin{array}{c}-4.75^{\star \star} \\
(0.48)\end{array}$ & $\begin{array}{c}-4.61^{\star \star} \\
(0.53)\end{array}$ \\
\hline$N$ & 8,499 & 8,336 & 7,835 & 7,724 & 7,724 & 8,336 \\
\hline Log Likelihood & $-1,352.94$ & $-1,323.34$ & $-1,268.10$ & $-1,243.15$ & $-1,247.81$ & $-1,319.14$ \\
\hline Pseudo $R^{2}$ & 0.72 & 0.72 & 0.72 & 0.72 & 0.72 & 0.72 \\
\hline
\end{tabular}

Notes: cells report logit coefficients with standard errors in parentheses; $1=$ Leave, $0=$ Remain. White British respondents residing outside of London only. Weighted by weight w10w11. ${ }^{* *} \mathrm{p}<0.01,{ }^{*} \mathrm{p}<0.05$, two-tailed test.

Source: Fieldhouse et al. (2019b). 
Table 5. Effect of evaluations of local and London economy on probability of supporting Leave

\begin{tabular}{llcc}
\hline & & \multicolumn{2}{c}{ Local economy } \\
\hline & & Better & Worse \\
London economy & Better & $0.62(0.49-0.74)$ & $0.76(0.54-0.98)$ \\
& Worse & $0.44(0.33-0.55)$ & $0.49(0.41-0.58)$ \\
\hline
\end{tabular}

Note: cells report expected probability of choosing Leave calculated from estimates in Table 4 Model 6 . Expected probabilities produced by manipulating Local economy and London economy while setting all other variables in the model at mean or modal values. Brackets report 95 per cent confidence intervals.

view their own economy as worse but the economy of Londoners as having improved. Furthermore, views of the financial standing of the out-group - Londoners - matter more than those of the geographically proximal in-group. This finding is consistent with our relative perceptions hypothesis (Hypothesis 3). ${ }^{16}$

\section{Conclusion}

The literature has been divided about the relative explanatory power of an economic vs. cultural basis for the widespread rise of populism. We demonstrate that these concepts are not entirely separable. Evaluations of economic conditions should take into account the group-based nature of economic improvements, relative assessments and resentments. If we do this, we find a combined role of economic evaluations for culturally and geographically defined groups that predicts support for populism and which also bridges a divide in the existing literature in empirically, conceptually, and theoretically useful and important ways.

We compared the importance of group-based economic assessments to the explanatory role of attitudes to immigration. We found that a group-based economic vote for Brexit plays a significant role in Brexit vote choices, and is a more useful measure of economics than 'standard' economic variables or a person's income, household-level economic evaluations or national-level economic evaluations. The evaluations of the out-group with respect to ethnic minorities are particularly important in driving these identified effects, but in-group assessments also play some part in this. If we are looking to identify an individual-level economic basis for support for populism, we need measures of group-based gains and losses, rather than using the standard economic voting variables. Furthermore, these effects are found net of immigration attitudes and a range of other possible confounding controls and remain statistically significant when we account for prior Brexit vote choice in a lagged panel design.

We conclude that a group-based economic vote has the potential to play an important role in explaining support for populist causes, and offers a more promising way to model the individuallevel role of economics than has been used, to date, which helps to reconcile aggregate-level findings about economics with group-based measures of economics at the individual level.

Our findings prompt several new directions for consideration. The first is whether our findings are replicable in other country contexts. While we have no reason to think there is anything particular about the in-group and out-group comparisons and tendencies to form resentments based on relative economic assessments, the importance of various different group-based assessments might vary depending on other key factors in specific elections, and the political salience and public awareness and anxiety about different cultural and economic changes.

Substantively, our findings suggest new directions for conceptualizing the basis of economic voting. We have identified substantial effects of relative assessments, and the importance of group-based assessments. Researchers might also usefully consider a range of different ways

\footnotetext{
${ }^{16}$ For comparison, we report results from performing a similar analysis on ethnic in-group/out-group models in Appendix Tables A9 and A10.
} 
and levels at which people assess the economic conditions of salient groups, especially given the group-based nature of political representation and policy making (see Thau 2019). It is plausible that voters recognize policy appeals aimed at different groups of voters (groups they may or may not identify with) and reward or punish parties for a wider range of group-based economic outcomes than we assess here. Our focus has been on explaining resentment-based voting for populist causes, but a range of different political outcomes can be conceived on the basis of group-based economic voting.

In relation to our understanding of populism, this article offers a way to bridge and move on from the two 'camps' on display in prior studies - between those advocating cultural threat explanations for populism and support for populist leaders, and those highlighting the primary role of economics. We do not doubt that there are unique aspects to both, but recognizing the overlap between cultural threat and relative economic assessments offers a conceptual and theoretical advancement in understanding the focal political outcomes, and is one way to reconcile these debates.

The failure to draw more explicit links between economic experiences, immigration, race and support for populism is surprising to us in view of the extensive literature on the role of material resources in realistic-conflict theory (Sherif 1966), inter-group threat (Stephan and Stephan 1985) and racial resentment (Kinder and Sanders 1996), all of which place economic competition at the heart of intergroup conflict. In this article we found that the perception that other groups are gaining economically demonstrates a strong and substantial relationship with support for Brexit, alongside a scenario in which those groups are gaining and you (or your group) is not. Furthermore, this effect does not apply just to perceptions about ethnic-minority immigrants; it also applies to comparisons of the economic gains made in London with those of the respondent's local community.

Acknowledgements. We wish to thank to thank the editors and reviewers of the British Journal of Political Science and colleagues who gave helpful comments in seminar presentations at: Indiana University, the London School of Economics, the University of Manchester, Nuffield College - University of Oxford, the University of Montreal, the 2018 European Political Science Association annual conference and the 2018 Midwest Political Science Association annual conference.

Data availability statement. Replication data for this article can be found in Harvard Dataverse at: https://doi.org/10.7910/ DVN/WBLE7E. The British Election Study data can be downloaded via: www.britishelectionstudy.com/data.

Supplementary material. Online appendices are available at https://doi.org/10.1017/S0007123420000551.

Financial support. Data collection for this research was supported by the Economic and Social Research Council British Election Study grant, Award ES/K005294/1.

\section{References}

Adler D and Ansell B (2020) Housing and populism. West European Politics 43(2), 344-365.

Altemeyer B (1981) Right Wing Authoritarianism. Winnipeg: University of Manitoba Press.

Ansolabehere S, Meredith M and Snowberg E (2014) Mecro-economic voting: local information and micro-perceptions of the macro-economy. Economics \& Politics 26(3), 380-410.

Arel-Bundock V, Blais A and Dassonneville R (2020) Do voters benchmark economic performance? British Journal of Political Science 1-13. Doi: 10.1017/S0007123418000236

Becker SO, Fetzer T and Novy D (2017) Who voted for Brexit? A comprehensive district-level analysis. Economic Policy 32(92), 601-650.

Berry WD, DeMeritt JHR and Esarey J (2010) Testing for interaction in binary logit and probit models: is a product term essential? American Journal of Political Science 54(1), 248-266.

Bobo L and Hutchings VL (1996) Perceptions of racial group competition: extending Blumer's theory of group position to a multiracial social context. American Sociological Review 61(6), 951-972.

Burgoon B et al. (2019) Populism and prosperity. Economic Policy (forthcoming)

Carreras M, Carreras Y and Bowler S (2019) Long-term economic distress, cultural backlash, and support for Brexit. Comparative Political Studies 52(9), 1396-1424. 
Clarke H, Goodwin M and Whiteley P (2017) Brexit: Why Britain Voted to Leave the European Union. Cambridge: Cambridge University Press.

Colantone I and Stanig P (2018) Global competition and Brexit. American Political Science Review 112(2), $201-218$.

Cramer KJ (2016) The Politics of Resentment: Rural Consciousness in Wisconsin and the Rise of Scott Walker. Chicago, IL: University of Chicago Press.

Donovan T and Redlawsk D (2018) Donald Trump and right-wing populists in comparative perspective. Journal of Elections, Public Opinion and Parties 28(2), 190-207.

Evans G and Andersen R (2006) The political conditioning of economic perceptions. The Journal of Politics 68(1), $194-207$.

Fetzer T (2019) Did austerity cause Brexit? American Economic Review 109(11), 3849-3886.

Fetzer T, Becker SO and Novy N (2018) Austerity, Immigration or Globalisation: Was Brexit Predictable? London: Social Market Foundation.

Fieldhouse E et al. (2019a) Electoral Shocks: The Volatile Voter in a Turbulent World. Oxford: Oxford University Press.

Fieldhouse E et al. (2019b) British Election Study Internet Panel Waves, 1-15. doi: 10.15127/1.293723.

Ford R and Goodwin M (2014) Revolt on the Right: Explaining Support for the Radical Right in Britain. London: Routledge.

Gest J (2016) The new Minority: White Working Class Politics in an age of Immigration and Inequality. New York: Oxford University Press.

Gest J, Reny T and Mayer J (2018) Roots of the radical right: nostalgic deprivation in the United States and Britain. Comparative Political Studies 51(13), 1694-1719.

Gidron N and Hall P (2017) The politics of social status: economic and cultural roots of the populist right. The British Journal of Sociology 68(Suppl. 1), S57-S84.

Goodwin M and Milazzo C (2017) UKIP: Inside the Campaign to Redraw the Map of British Politics. Oxford: Oxford University Press.

Green J, Hellwig, T and Fieldhouse, E (2021) Replication Data for: Who Gets What: The Economy, Relative Gains, and Brexit, https://doi.org/10.7910/DVN/WBLE7E, Harvard Dataverse, V1, UNF:6:M5Q0Ok40IvnAu/b4H0icPA== [fileUNF].

Hainmueller J and Hopkins DJ (2014) Public attitudes toward immigration. Annual Review of Political Science 17, 225-249.

Hays J, Spoon J and Lim J (2019) The path from trade to right-wing populism in Europe. Electoral Studies 60. Doi: 10.1016/ j.electstud.2019.04.002

Heath A, Evans G and Martin J (1994) The measurement of core beliefs and values: the development of balanced socialist/ laissez faire and libertarian/authoritarian scales. British Journal of Political Science 24(1), 115-132.

Heath A, et al. (1999) British national sentiment. British Journal of Political Science 29(1), 155-174.

Ho AK et al. (2015) The nature of social dominance orientation: theorizing and measuring preferences for intergroup inequality using the new $\mathrm{SDO}_{7}$ scale. Journal of Personality and Social Psychology 109(6), 1003.

Ho AK et al. (2012) Social dominance orientation: revisiting the structure and function of a variable predicting social and political attitudes. Personality and Social Psychology Bulletin 38, 583-606.

Hobolt SB (2016) The Brexit vote: a divided nation, a divided continent. Journal of European Public Policy 23(9), 1259-1277.

Hofstadter R (1967) The Paranoid Style in American Politics. New York: Vintage Books.

Hogg MA and Abrams D (1988) Social motivation, self-esteem and social identity. In D Abrams and MA Hogg (eds), Social Identity Theory: Constructive and Critical Advances. Hemel Hempstead, UK: Harvester Wheatsheaf, pp. 28-47.

Iakhnis E et al. (2018) Populist referendum: was Brexit an expression of nativist and anti-elitist sentiment? Research and Politics 5(2), 2053168018773964.

Ivarsflaten E (2008) What unites right-wing populists in Western Europe? Comparative Political Studies 41, 3-23.

Jennings W and Stoker G (2017) Tilting towards the cosmopolitan axis? Political change in England and the 2017 general election. Political Quarterly 88(3), 359-369.

Kaufmann E (2016) Its NOT the economy, stupid. LSE British Politics and Policy blog, 7 July. Available from https://blogs. lse.ac.uk/politicsandpolicy/personal-values-brexit-vote/ (accessed 14 December 2020).

Kaufmann E (2018) Whiteshift: Populism, Immigration and the Future of White Majorities. London: Penguin.

Kinder D and Kiewiet D (1981) Sociotropic politics: the American case. British Journal of Political Science 11(2), 129-161.

Kinder DR and Kam CD (2009) Us against Them: Ethnocentric Foundations of American Opinion. Chicago, IL: University of Chicago Press.

Kinder DR and Sanders LM (1996) Divided by Color: Racial Politics and Democratic Ideals. Chicago, IL: University of Chicago Press.

Lewis-Beck MS, Nadeau R and Elias A (2008) Economics, party, and the vote: causality issues and panel data. American Journal of Political Science 52(1), 84-95.

Margalit Y (2012) Lost in globalization: international economic integration and the sources of popular discontent. International Studies Quarterly 56(3), 484-500.

Montgomery JM, Nyhan B and Torres M (2018) How conditioning on posttreatment variables can ruin your experiment and what to do about it. American Journal of Political Science 62(3), 760-775.

Morrison KR and Ybarra $\mathbf{O}$ (2008) The effects of realistic threat and group identification on social dominance orientation. Journal of Experimental Social Psychology 44(1), 156-163. 
Mutz DC (2018) Status threat, not economic hardship, explains the 2016 presidential vote. Proceedings of the National Academy of Sciences 115(19), E4330-E4339.

Mutz DC and Mondak JJ (1997) Dimensions of sociotropic behavior: group-based judgements of fairness and well-being. American Journal of Political Science 41, 284-308.

Norris P and Inglehart R (2018) Cultural Backlash: Trump, Brexit, and the Rise of Authoritarian Populism. New York: Cambridge University Press.

Norton MI and Sommers SR (2011) Whites see racism as a zero-sum game that they are now losing. Perspectives on Psychological Science 6(3), 215-218.

Olson J (2008) Whiteness and the polarization of American politics. Political Research Quarterly 1, 704-718.

Pardos-Prado S and Xena C (2019) Skill specificity and attitudes toward immigration. American Journal of Political Science 63(2), 286-304.

Pattie C and Johnston R (1995) 'It's not like that round here': region, economic evaluations and voting at the 1992 British general election. European Journal of Political Research 28(1), 1-32.

Rogers J (2014) A communotropic theory of economic voting. Electoral Studies 36, 107-116.

Schaffner BF, MacWilliams M and Nteta T (2018) Understanding White polarization in the 2016 vote for president: the sobering role of racism and sexism. Political Science Quarterly 133(1), 9-34.

Sherif M (1966) In Common Predicament: Social Psychology of Intergroup Conflict and Cooperation. Boston, MA: Houghton Mifflin.

Sidanius J and Pratto F (1999) Social Dominance: An Intergroup Theory of Social Hierarchy and Oppression. Cambridge: Cambridge University Press.

Sniderman PM, Hagendoorn L and Prior M (2004) Predisposing factors and situational triggers: exclusionary reactions to immigrant minorities. American Political Science Review 98(1), 35-49.

Stephan WG and Renfro CL (2002) The role of threats in intergroup relations. In D Mackie and ER Smith (eds), From Prejudice to Intergroup Emotions. New York: Psychology Press, pp. 191-208.

Stephan WG and Stephan CW (1985) Intergroup anxiety. Journal of Social Issues 41, 157-175.

Tajfel H (ed.). (1978) Differentiation Between Social Groups: Studies in the Social Psychology of Intergoup Relations. Oxford: Academic Press.

Tajfel H and Turner JC (1979) An integrative theory of intergroup conflict. In WG Austin and S Worchel (eds), The Social Psychology of Intergroup Relations. Monterey, CA: Brooks/Cole, pp. 56-65.

Tankersley J (2016) How Trump Won the Revenge of Working Class Whites. The Washington Post, 9 November. Available from https://www.washingtonpost.com/news/wonk/wp/2016/11/09/how-trump-won-the-revenge-of-working-class-whites/ (accessed 14 December 2020).

Thau M (2019) How political parties use group-based appeals: evidence from Britain 1964-2015. Political Studies 67(1), 63-82.

Cite this article: Green J, Hellwig T, Fieldhouse E (2022). Who Gets What: The Economy, Relative Gains and Brexit. British Journal of Political Science 52, 320-338. https://doi.org/10.1017/S0007123420000551 